\title{
On-demand work in platform economy: implications for sustainable development (V7
}

22.5.2018)

Cite this paper as: Seppänen L., Hasu M., Käpykangas S., Poutanen S. (2019) On-Demand Work in Platform Economy: Implications for Sustainable Development. In: Bagnara S., Tartaglia R., Albolino S., Alexander T., Fujita Y. (eds) Proceedings of the 20th Congress of the International Ergonomics Association (IEA 2018). IEA 2018. Advances in Intelligent Systems and Computing, vol 825. Springer, Cham First Online 08 August 2018

DOI https://doi.org/10.1007/978-3-319-96068-5_86

Springer, Cham

Print ISBN 978-3-319-96067-8

Online ISBN 978-3-319-96068-5

Laura Seppänen, Finnish Institute of Occupational Health, Finland Mervi Hasu, University of Oslo, Norway

Sari Käpykangas, Finnish Institute of Occupational Health, Finland Seppo Poutanen, University of Turku, Finland

\section{Introduction}

The global importance of crowd or on-demand work via digital platforms is increasing. Platform enterprises create and manage two- or many-sided markets by enabling suppliers and buyers of services meet in a flexible and scalable way, creating new economic efficiencies. However, platform work may also increase invisibility, uncertainty, risks, and competition for workers (de Stefano, 2016). This paper investigates the sustainability of on-demand work through a dynamic analysis of the resources available to workers when facing an abrupt change in their work organization. Our empirical case is a platform-driven food courier company in the Helsinki region, Finland. We discuss the resources we found in the light of the immunity, control and fungibility mechanisms that lead to both opportunities and vulnerabilities for the on-demand workers (van Doorn, 2017). The paper yields practice-based empirical insights of how immunity, control and fungibility are experienced by workers, and thus add our understanding of the often invisible and dark side of on-demand work. At the end, we present our conclusions regarding research on sustainable development.

\section{On-demand work, its mechanisms and sustainable development}

Platform work is varied, and consists of online work in which tasks are carried out completely via the internet and on-demand work that offers and assigns local work activities, such as transport, through digital platforms. The tasks in both of these types of work can be either routine or sophisticated, requiring expertise. Our case, food courier work, is of the on-demand and routine type.

Niels van Doorn (2017), focusing on simple online and on-demand work, discusses the platform mechanisms of immunity, control and fungibility. Immunitary strategies consist of worker arrangements without employee benefits, information asymmetries, and outsourced or algorithmic management systems that shield platform owners from having to deal directly with the workers 
providing services. Control is manifested through, for example, real-time algorithmic management or in performance metrics comparing on-demand workers. Fungibility is fueled by a surplus population of underemployed gig workers who may depend on this type of irregular, underpaid work.

The platform economy affects the triple bottom line; people, planet and prosperity, of sustainability in complex ways. Sustainable work is able to not only function in its environment and achieve economic or operational goals; it also has the capacity to build on and promote the development of the human, social, ecological, and economic resources in its operations (Docherty, Kira and Shani 2009). Our investigation is mainly of the human and social resources needed or used in maintaining the functioning of on-demand work systems.

\section{Data and methods}

Our data consist of three food courier interviews in a platform company called Deli. Each transcribed interview consists of about 11 000-13000 words. First we analyzed the data contents to obtain an overview of courier activity and the company. Then we divided the interviews into episodes and coded them inductively using ATLAS.ti software. This made us pay special attention to the interviewees' talk about work shifts, especially their management's implementation of a new way of assigning these shifts to freelancers. We call this change the 'new shift system'.

Next, we analyzed all episodes concerning work shifts. Our main questions were: What objects orient couriers when they talk about work shifts? What problems do they express, and what resources they use in these instances? We connect the notion of resource from sustainability literature with organizational psychology and activity theories. In the latter, resources as instruments not only enable but also modify the way in which people think and act in their objectoriented activities (Beguin \& Rabardel, 2000; Engeström, Puonti \& Seppänen, 2003). As well as social and material resources in work environments, workers use psychological, cognitive and emotional resources to reach the goals of their work. Work may either deplete or increase these resources (Hobfoll, 2002). The concept of object, meaning a motivational 'thing' under elaboration, helps us understand the intentional system in which resources are needed or used.

\section{Findings}

\subsection{Deli company and food couriers}

Since August 2015, Deli has functioned in Finland as an intermediary between restaurants and food buyers. It has developed its own internet-based software which enables customers to see, select and pay for food offered by restaurants. The platform transmits the order to both the courier and the restaurant. The relatively simple task of a courier is to accept the order, ride or drive to the restaurant, collect the food and the address, and deliver the food to the customer. The orders are controlled by software, but the personnel, called 'dispatchers', are available if a courier has problems. At the time of the interviews in June 2017, the two managers in Finland had left the company and the operation was managed from abroad. Table 1 presents the features of the interviewed couriers. 
Table 1. Features of interviewees

\begin{tabular}{llll}
\hline Name & Actual occupational situation & $\begin{array}{l}\text { Working hours per } \\
\text { week at Deli }\end{array}$ & $\begin{array}{l}\text { Length of } \\
\text { employment at Deli }\end{array}$ \\
\hline \multirow{2}{*}{ Tom } & $\begin{array}{l}\text { Full-time contractor at Deli. In } \\
\text { addition to courier work by bicycle, } \\
\text { Tom is Team supervisor. }\end{array}$ & $25-30$ & 20 months \\
& Part-time freelancer doing courier & 8-25, mostly on & \\
Jack & work by bicycle. Jack has another job & week ends & 19 months \\
& linked to his studies. & & \\
& Full-time freelancer working with his & Before 30-40, & 16 months \\
Samuel & car. & now 15-20 &
\end{tabular}

In Deli terminology, a contractor is a worker, like Tom for instance, who has a normal employment contract with the employer who pays legal duties. Tom has supervisory tasks, belongs to the Deli community, and has a better salary and easier access to work shifts than freelancers. $A$ freelancer, like Jack and Samuel, is self-employed and personally bears any risks and costs. Both contractors and freelancers are only paid for work done. Both can be off work without income whenever they like according to whether they can afford to be. In this paper we use the word 'worker' to refer to all who offer their work to platform companies. Next, we analyze the food couriers' objects in relation to work shifts.

\subsection{Couriers' two objects}

According to our analysis, food couriers strive for two major objects in terms of work shifts: 1 aspiring for liberty and flexibility, and 2 obtaining work shifts. In the first case of aspiring for liberty, the work shift system can be a resource for couriers (Excerpt 1).

Excerpt 1.

Interviewer: Where does work in the on-demand work fit into that, in your, whole life situation? How would you describe?

Tom: It allows a lot of liberty, eventually in terms of working shifts, 'cause it's a work usually between 10 and 22 . So the flexibility, the potential flexibility depending on your experience on the job and the contract you have, allows you to work day or evening. That's a liberty. The same for non-working period, which may not be considered as holidays.

The shift system was a resource also for Jack, allowing him to pick shifts on weekends only. The couriers also created new informal communication resources for giving away or exchanging work shifts with their colleagues. In the second object, rather than a resource, work shifts become part of the motive of earning income. The couriers' performance is constantly monitored: the better their performance, the more easily they get the work shifts they want. Most couriers try to work above average performance.

\subsection{The new shift system}

The new shift system, experienced as unfair by all interviewees, makes the object of obtaining work shifts critical. Table 2, Column A contains a re-constructed narrative from Samuel's interview. It shows how shift managers implemented different versions of the new system run by Deli's 
algorithms. Column B (Table 2) examines how Samuel experiences the steps. Two kinds of unfairness can be read here: procedural unfairness, meaning that the quick steps of the process do not provide the couriers with equal opportunities, and unfairness in terms of income. For instance, in the new shift system, Samuel had 10-15 hours less work than before. This was critical, as Deli courier work was his only income at the time of the interview. The most severe problem causing uncertainty and suspicion towards Deli was when shift managers claimed not to be in control of the new shift system.

Samuel's individual and collective resources in this situation, and our interpretations of these resources are shown in Table 2, Columns $C$ and $D$. The majority of these resources are cognitive or emotional, for making sense of the situation; such as the metaphor of the new shift system: 'as throwing a bone in the middle of ten dogs' (Row 6). Samuel is proactive in speaking up about unfairness, which we interpret as an 'acting resource'. The most important resource during the crisis of the new shift system seems to have been the team community and its trusted captain. Couriers like Samuel drive their cars alone and do not meet their colleagues face to face during their work. The two promising resources (Rows 3 and 9) that might have been of help remain only potential in Samuel's narrative.

The question of trade unions was taken up as a potential resource. Freelancers can become members of unions, and if there are

Table 2. Samuel's narrative, problems and resources in new shift system. 


\begin{tabular}{|c|c|c|c|c|}
\hline Steps & Description of step in narrative & $\begin{array}{l}\text { Samuel's reaction or } \\
\text { experienced problem }\end{array}$ & Resource & Interpretation of resource \\
\hline 1 & $\begin{array}{l}\text { The management informed workers of the new shift } \\
\text { system. Instead of their availability, freelancers would } \\
\text { now report when they are not able to work. }\end{array}$ & This sounded fine. & $\begin{array}{l}\text { The old shift planning system } \\
\text { worked well }\end{array}$ & $\begin{array}{l}\text { Cognitive resource: Old system is a } \\
\text { positive reference }\end{array}$ \\
\hline 2 & $\begin{array}{l}\text { Unavailablity times would have to be announced once } \\
\text { a week, on Sunday at } 12 \text { o'clock. }\end{array}$ & $\begin{array}{l}\text { This is too short } \\
\text { notice. }\end{array}$ & & \\
\hline 3 & $\begin{array}{l}\text { Shift managers kindly asked drivers not to take too } \\
\text { many shifts. }\end{array}$ & $\begin{array}{l}\text { This was just advice, } \\
\text { they did not control } \\
\text { it. }\end{array}$ & $\begin{array}{l}\text { There was a channel for } \\
\text { exchanging or giving away shifts, } \\
\text { but Samuel did not see this } \\
\text { happen. }\end{array}$ & $\begin{array}{l}\text { Material resource, but remained } \\
\text { an unrealized possibility. }\end{array}$ \\
\hline 4 & $\begin{array}{l}\text { Two days later, the management said there was a } \\
\text { problem in the system, and shifts would be announced } \\
\text { on the Open shifts channel. Anyone could apply and } \\
\text { automatically get these shifts. }\end{array}$ & $\begin{array}{l}\text { This message was } \\
\text { sent only two hours } \\
\text { before the shifts } \\
\text { were made available. }\end{array}$ & $\begin{array}{l}\text { Captain told workers that in } \\
\text { Tampere, two car drivers got all } \\
\text { the shifts, and the rest got } \\
\text { nothing. }\end{array}$ & $\begin{array}{l}\text { Reference as cognitive resource } \\
\text { about the generality and gravity of } \\
\text { the problem. }\end{array}$ \\
\hline 5 & & $\begin{array}{l}\text { There has been a lot } \\
\text { of complaints about } \\
\text { the system. }\end{array}$ & $\begin{array}{l}\text { Samuel was among the first to } \\
\text { complain about unfairness of the } \\
\text { new shift system. }\end{array}$ & $\begin{array}{l}\text { Action resource: Own social } \\
\text { actions (complaining) }\end{array}$ \\
\hline 6 & $\begin{array}{l}\text { The management just said 'We are sorry. We have no } \\
\text { control over this. It is done abroad in the main centre } \\
\text { of Deli" }\end{array}$ & This is really weird. & $\begin{array}{l}\text { It is like "throwing a bone in the } \\
\text { middle of ten dogs to fight about } \\
\text { it" }\end{array}$ & $\begin{array}{l}\text { Metaphor as a cognitive resource } \\
\text { for making sense }\end{array}$ \\
\hline 7 & $\begin{array}{l}\text { The management promised to inform workers of the } \\
\text { day on which the shiftsare announced. Everybody was } \\
\text { waiting for the "big bang". }\end{array}$ & $\begin{array}{l}\text { Fortunately, Samuel } \\
\text { got } 20 \text { hours, but this } \\
\text { was } 10-15 \text { hours less } \\
\text { than normal. }\end{array}$ & Samuel felt lucky & $\begin{array}{l}\text { Cognitive and emotional resource: } \\
\text { Sense of irony in feeling lucky. }\end{array}$ \\
\hline 8 & One-way communication & $\begin{array}{l}\text { It would be nice to } \\
\text { get explanations. }\end{array}$ & $\begin{array}{l}\text { Team and captain communicated } \\
\text { via a mobile app. }\end{array}$ & $\begin{array}{l}\text { Community resource (team } \\
\text { support), material resource of } \\
\text { communication app. }\end{array}$ \\
\hline 9 & Managed from abroad. & $\begin{array}{l}\text { Managers don't } \\
\text { seem to understand } \\
\text { how unfair it is. }\end{array}$ & $\begin{array}{l}\text { The captain will check and } \\
\text { redistribute shifts, but Samuel } \\
\text { does not believe this will work. }\end{array}$ & $\begin{array}{l}\text { Potential and unlikely solution } \\
\text { resource. }\end{array}$ \\
\hline 10 & $\begin{array}{l}\text { New shift system began at beginning of summer, } \\
\text { ending a campaign and competition with a rival } \\
\text { company. }\end{array}$ & $\begin{array}{l}\text { New shift system is a } \\
\text { complete mess and } \\
\text { unpleasant. }\end{array}$ & $\begin{array}{l}\text { Understanding of factors } \\
\text { affecting demand for courier } \\
\text { work. }\end{array}$ & Cognitive resource \\
\hline
\end{tabular}


enough members in a company, the union can indeed take action. However, this was not the case at Deli. An interesting resource we found in the data was the couriers' image of Deli as a 'relaxed' and positively different place in which to work (Excerpt 2).

\section{Excerpt 2.}

Interviewer: (...) what then are the biggest problems if you think, potential problems if there are, so what would how would you describe them, doing this work for Deli?

Samuel: You mean things that, are affecting me or..

Interviewer: Yes things that are affecting your wellbeing and your, sense of, dignity or whatever sort of..

Samuel: I don't know. I don't, see, except the recent things, like yeah, I think it's affecting my dignity that I have to fight to, with other, with colleagues to get some shifts. Apart from that, I don't see anything, from that point of view I think, that that's okay. There is no, the work is when the work is done fine there is no, pressure from anybody and, I think that it's quite, it's a young company so I know it's also, behaving in a different way than the other places where I used to work. It's a bit more I don't know, relaxed and, I don't know, in a way.

We interpret that this modern, relaxed image of the company may help couriers tolerate unfairness or other downsides to their work. We depicted aspiring for liberty and flexibility on the one hand, and obtaining work shifts on the other hand, as two major work shift-related objects for couriers. Excerpt 3 shows how these two objects are in conflict with one another. At the end of this excerpt, Samuel interestingly expands the object, looking at his on-demand job from a general societal perspective.

\section{Excerpt 3.}

Interviewer: Would you prefer, a permanent employment contract or are you content with this freelancer contract? How would you feel about it?

Samuel: Well there's two [laughs] point of view.

Interviewer: Please, open up it a bit.

Samuel: Especially now that since, I don't know since two weeks there is a different system of, attribution of the shifts, so since two weeks I got way less, working time, and this system have touched only the freelancers. So in my case I would really like to have more hours and be secure. But, from my other point of view, this is not my, dream job and this is..

Interviewer: This is temporary.

Samuel: ..really temporary till I figure out, what I will do. And I really enjoy to be free and grab an opportunity, when I can and just say "Okay I'm away" and.

Interviewer: That's true.

Samuel: So..

Interviewer: It's a kind of a, it's a mixed, mixed feelings about yes.

Samuel: Yeah. So, I would say that, yeah I'm quite happy about the, how it is, even though I'm conscious of certain things that are not good.

I: Not good from your point of view.

$\mathrm{R}$ : Yeah, for the society in general.

\section{Discussion and conclusion}

In on-demand work, it is not illegal for the company to reduce freelancers' rights - as occurred with the new shift system in Deli. Platform owners reserve the right to modify their agreements with freelancers one-sidedly at any time, which renders freelancers' relation with platform companies highly insecure (van Doorn, 2017). Changes reveal immunitary strategies of platform companies: information asymmetries (one-sided communication, no explanations, and uncertainty about the future), and algorithmic management systems that shield platform owners from having to deal directly with workers (van Doorn 2017). The importance of contractual and regulatory resources is only really revealed when they are absent. 
The team community was one of the most significant resources for the couriers. Platform companies, matching merely service supply and demand with their algorithms, do not have to offer teams or supervision to freelancers. Having such structures may suggest to authorities that it is question of employment, and that the platform should fulfill employers' duties. Superiors also have a control function at Deli: Monitoring couriers' performance. Platform companies commonly control their workers using various kinds of performance metrics, including customer ratings (van Doorn, 2017). Feedback through comparisons to other workers, as well as overall rankings, create a hierarchical space in which all workers relate competitively to one another. Interestingly, our data show how organizational practices lacking management control, for instance, a few workers being able to pick up the majority of gigs, may aggravate competition and a sense of unfairness.

The business idea of platform enterprises is transferring risks, at least partially, from the company to workers. Despite this, these companies sustain their activities and grow. Considering the poor resources and unfairness, how is this possible? We argue that the liberty and flexibility offered by platform companies is what attracts many workers. A good image, such as being a modern or relaxed workplace, is appealing to assumedly young workers. In addition to economic gains, sustaining platform work is fueled by fungibility (van Doorn, 2017): Platform companies, knowing that unsatisfied workers will leave, constantly recruit new workers. This strategy is successful because there is a surplus population of underemployed gig workers; companies can keep hiring rates high and labor costs low (van Doorn, 2017). Food courier work is easily fungible.

Our findings generate implications for research on sustainable development in on-demand work. First, quick changes are interesting events for examining sustainability resources (Docherty et al., 2009). Second, the empirical analysis of workers' objects offers a dynamic, systemic and motivational view of sustainability resources (Pereira-Querol, Seppänen \& Jackson-Filho, 2015; Seppänen, 2017). Resources for on-demand workers, especially those lacking in our case, need to be strengthened, but we have better not to assess on-demand work on the grounds of the old employment regime. As Marina Gorbis (2016) writes, on-demand work creates challenges, but it also bears the seeds of something great. The new operating system of platform organizing can be an opportunity to build something better. 


\section{References}

Béguin, P., \& Rabardel, P. (2000). Designing for instrument mediated activity. Scandinavian Journal of Information Systems, 12, 173-190.

de Stefano, V. (2016). The rise of the "just-in-time worforce": On-demand work, crowdwork and labour protection in the "gig-economy". Geneva, International Labour Organization. Conditions of Work and Employment Series No. 71

Docherty, P., Kira, M. \& A. B. R. Shani, A. B. R. (Eds.), Creating sustainable work systems. London: Routledge.

Engeström, Y., Puonti, A., \& Seppänen, L. (2003). Spatial and temporal expansion of the object as a challenge for reorganizing work. In S. G. Davide Nicolini, Dvora Yanow (Ed.), Knowing in organizations: A practice-based approach (pp. 151-186): M. E. Sharpe.

Gorbis, M. (2016). Designing a new operation system for work. In E. Kilpi (Ed.), Perspectives on new work. Exploring emerging conceptualizations: Sitra Studies 114.

Hobfoll, S. E. (2002). Social and psychological resources and adaptation. Review of General Psychology, 6, 307-324.

Pereira-Querol, M., Seppänen, L., \& Jackson Filho, J. M. (2015). Understanding the motivational perspectives of sustainability: A case of biogas production. Production, 25(2), 266-277.

Seppänen, L. (2017). Learning challenges and sustainable development: A methodological perspective. Work: A Journal for Prevention, Assessment and Rehabilitation, 57(3), 315-324.

van Doorn, N. (2017). "Platform labor: on the gendered and racialized exploitation of low-income service work in the 'on-demand' economy." Information, Communication and Society 20(6): 898-914 